\title{
EVALUATION OF WHEELCHAIR BASKETBALL SKILL PERFORMANCE OF WHEELCHAIR BASKETBALL PLAYERS IN DIFFERENT GAME POSITIONS
}

\author{
Kęstutis Skučas ${ }^{1}$, Stanislovas Stonkus ${ }^{1}$, Bartosz Molik ${ }^{2}$, Vytautas Skučas ${ }^{1}$ \\ Lithuanian Academy of Physical Education ${ }^{1}$, Kaunas, Lithuania, Academy of Physical Education in \\ Warsaw $^{2}$, Warsaw, Poland
}

Kęstutis Skučas. PhD of Social Sciences, Assoc. Prof. at the Department of Adapted Physical Activity, Lithuanian Academy of Physical Education. Research interests - rehabilitation of the disabled, adapted physical activity.

\begin{abstract}
In wheelchair basketball the evaluation of the quality of disabled players 'movement, motion and action variety, sensomotoric, intelectual, social interaction skills, coordinative and physical abilities besides the natural tests (Brasile, 1986), quantitative and qualitative play results (technical actions carried out by a player during a game and during a minute of a game) are considered to be objective and informative.

The aim of the research was to state and evaluate the playing skills of wheelchair basketball players in different game positions (a playmaker, a forward, a center) in official competitions. The play of 32 baketball players was under research. Aiming to analyse playing results of wheelchair basketball players in different game positions 20 games were video recorded by camera "Panasonic NV-GS27". The following actions of the players (playmakers, forwards, centers) with different functions in the team were recorded: playing time, passing, dribbling, shooting and its efficiency, rebounding and other important technical actions characterizing the activity of the players during the game.

The integral preparation, ability to play, the playing quality were evaluated according to the methods of D. Byrnes and B. Hendrick (1994), giving high or low marks for each action. Results showed that centers were the most active ones, carrying out on average 2.5 actions per minute (forwards - 2.1, playmakers - 1.2), shooting 16 times per game (forwards - 7.7, playmakers - 5). The most universal players were also the centers, their passing and dribbling actions making up 25\%, shooting actions - 20\% of all the movements. The most accurate main technical actions were carried out by the centers: their shooting accuracy was 36\% (that of wing players and playmakers being 30\%). Centers' integral qualification and playing skills (according to the methods used) were the highest rated +42 points.

Quantitative and qualitative playing results and the results of integral preparation of wheelchair basketball players in center position were significantly better than those of the playmakers and forwards.
\end{abstract}

Keywords: wheelchair basketball, quantitative and qualitative playing results, integral qualification, player's game positions.

\section{INTRODUCTION}

$\mathrm{W}$ heelchair basketball is a sport game with a ball, adapted to disabled people that are physically handicapped. It was introduced in the USA in 1949. After World War II it was used as a form of integration, socialization and rehabilitation of disabled people. In 1960 the game became popular in many countries all over the world. Now wheelchair basketball is used and known as a form of adapted physical activity and sport for people with physical disabilities and helps to improve their physical state, makes the socialization process more effective.

The quality of basketball actions and ability to play basketball can be specified using both the field test data and a total sum of actions carried out by the team during the game (Stonkus, 2001; Skučas, Stonkus, 2002).

The complex structure of ability to practise technical actions and their units, ability to play are influenced by factors such as sensomotoric, 
intelectual, social interaction skills, coordination and team abilities. Abilities and skills of the basketball players are characterized by quantitative and qualitative results of the players during the game, while dynamics of the results is specified by playing tendencies (Stonkus, 2001).

In order to determine and evaluate the quality of the movements, the variety of actions, sensomotoric, intelectual, social interaction skills, the coordination and physical abilities of disabled athletes playing wheelchair basketball it is recommended to collect not only natural (Walandewijck et al., 1999; Molik, Kosmol, 2003; Brunelli et al., 2006) test data, but also the data of qualitative and quantitative play results, which are achieved by players during the game and in 1 minute of the game (Hedrick et al., 1994; Molik, Kosmol, 2001; Walandewijck et al., 2003).

In order to better understand the main features of wheelchair basketball it is necessary to take into account objective quantitative and qualitative playing results of the players during the competitions. On this point of view there are important studies about the type of the player's actions in different playing positions during the team game (playmakers, wings, center forwards).

Research and conclussions of this kind have never been described in scientific literature. In this respect the research is new and relevant.

The aim of the research was to state and evaluate the playing skills of wheelchair basketball players in different game positions (a playmaker, a forward, a center) in official competitions.

\section{RESEARCH METHODS AND ORGANIZATION}

The play of 32 baketball players was under research. Aiming to analyse the playing results of wheelchair basketball players in different game positions 20 games were video recorded by camera "Panasonic NV-GS27". The mean age of the players was 31.24 years. All the players participating in the current study had at least five and more years of experience playing wheelchair basketball on the national and international level. The players were divided into three groups according to their playing position during the game: playmakers - 9 , forwards - 11, centers - 12. Also the best players of each group were recorded. The research was carried out in 2006 during the Lithuanian Wheelchair Basketball Championship (6 games) and international tournaments in Lithuania and Poland (14 games).
The basic movements of the game were recorded. According to D. Byrnes and B. Hendrick (1994) methodology the following actions of the players (playmakers, forwards, centers) with different functions in the team were recorded in a special protocol: playing time, passing, dribbling, shooting and its efficiency, rebounding and other important technical actions characterizing the activity of the players during the game.

The integral qualification, ability to play, the playing quality were evaluated according to the methods of D. Byrnes and B. Hendrick (1994), giving high or low marks for each action:

1. Back picks +4

2. 2-point field goals made +5

3. 2-point field goals missed -3

4. 3-point field goals made +6

5. 3-point field goals missed -4

6. Foul goals made +4

7. Foul goals missed -2

8. Offence rebounds +4

9. Defensive rebounds +4

10. Personal fouls -2

11. Assists +5

12. Turnovers -6

13. Bloked shots +5

14. Steals +5

15. Forced turnovers on defence +6

16. Technical fouls -10

The results of the research were analysed using the SPSS 12.0 program package. One-way analysis of variance (ANOVA) was used to compare the results of the players of different playing positions and groups. Newman-Keul's analysis was used for post-hoc comparisons. The level of $\mathrm{p}<0.05$ was considered as significant.

\section{RESULTS}

On average playmakers $(n=9)$ played $32 \mathrm{~min}$. per game, made 37 actions in a game and 1.2 action in one minute of the game (as shown in the Table). The largest part of the technical actions were passings - $33 \%$, dribbling - $21 \%$, shootings $-16 \%$ (as shown in the Figure). 2-point shooting accuracy was $30 \%$, fouls shooting accurancy was $25 \%$.

The best playmaker made 80 actions in a game and 2.2 action in 1 game minute. $29 \%$ of actions were dribbling $27 \%$ - passing and $15 \%$ - shootings. Shooting accuracy was $33 \%$, fouls shooting $33 \%$, scored on average 9 points in a game. 


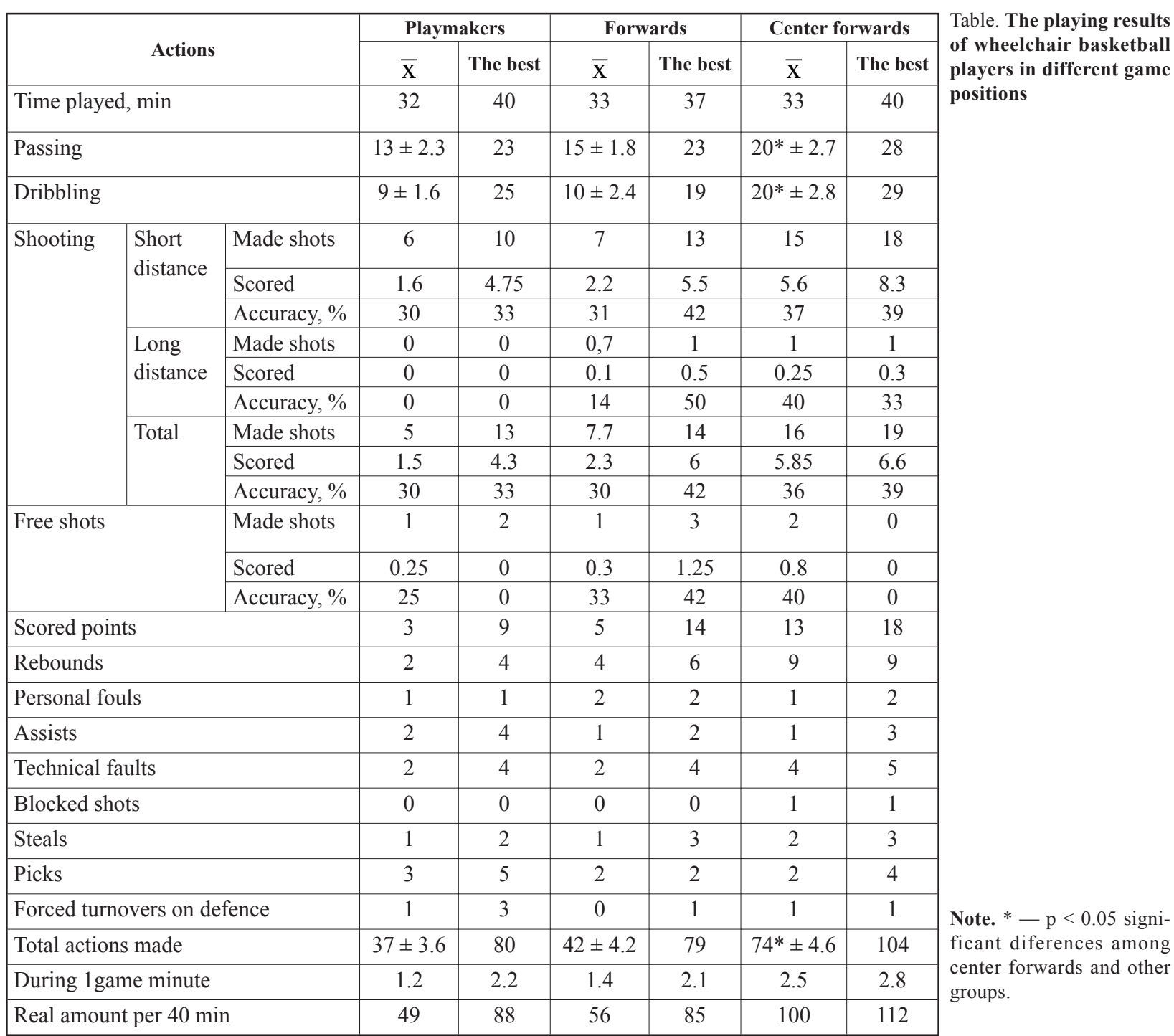

The forwards played 33 minutes per game, made 42 actions in a game and 1.4 action in 1 game minute. Passings made up 33\%, dribbling $22 \%$, shootings $-17 \%$ of the actions. Their shooting accuracy was $30 \%$, and they scored 5 points in a game.

The results of the best forward were significantly better than an average mean. The best athlete played 37 minutes during the game, made 79 actions (2.1 in 1 game minute). $29 \%$ of the actions were passing, dribbling - $24 \%$, shootings $-18 \%$. Very good shooting accuracy was $42 \%, 14$ points scored during the game (shown in the Figure and the Table).

The centers played 33 minutes during the game on the average and made 74 actions per game (2.5 in 1 game minute). Passing and dribbling were $25 \%$, shootings $-20 \%$ of all the actions. Their shooting accuracy was $36 \%$, and they scored 13 points per game on the average.

On the average the best center played $36 \mathrm{~min}$ utes per game, made 102 actions (2.8 during 1 played minute). Passing was $27 \%$, dribbling $28 \%$ and shootings - 17\%. Shooting accuracy was $39 \%$, on the average 14 points were scored per game.

\section{DISCUSSION}

According to the wheelchair basketball rules each team has to consist of players with different level of impairment because of limited total point number of the players in the field during the game (Coubariaux, 1994). According to the international rules the total point limit is 14 points. Because of that all players with different number of classification points have different functions in the field during the game. Playmakers are usually $1-1.5$ point players, forwards are $3-4$ point players, centers $-4-4.5$ point players (Dewell, 2001).

The results of our research revealed the fact that the most active players were centers carrying out on the average 2.5 actions per minute played 
Figure. Average results of technical actions of the players in different playing positions during the game
Note. $*-p<0.05$ significant differences among groups.

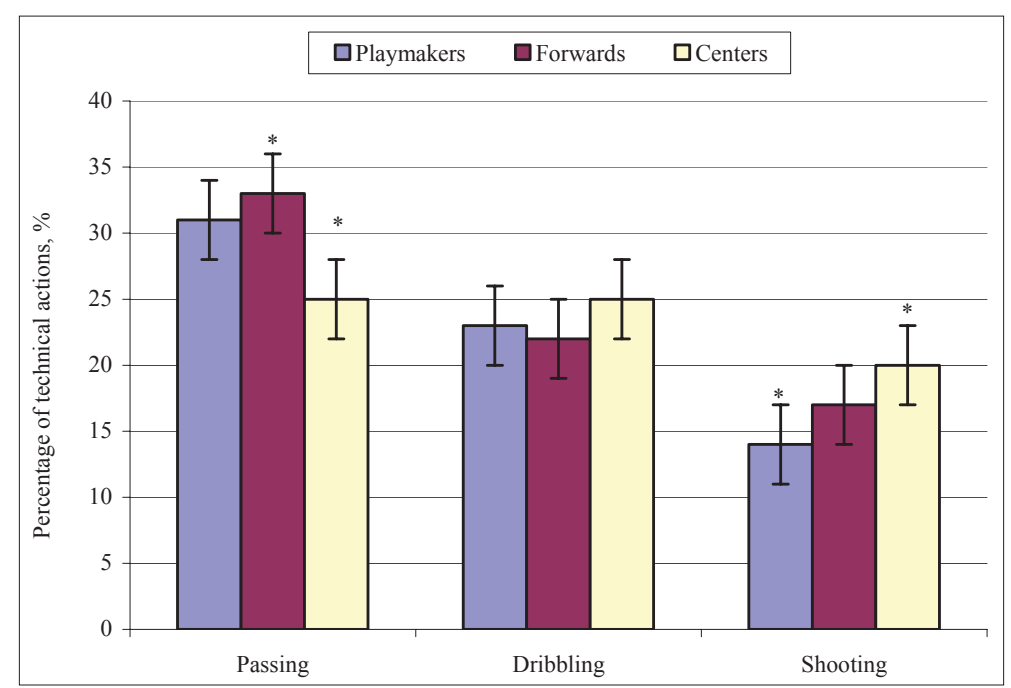

best 39\%), foul shooting accuracy - 40\%. The lowest number of technical faults was produced by playmakers and forwards. The best qualitative results of the center forwards can be explained by the fact that centers are tall, and most of them adjusted their wheelchairs to the highest sitting position, thus making it difficult to stop them shooting and scoring. Besides, center forwards usually have minimal impairment, their sitting position is good and stable at the shooting moment.

The results of integral preparation, ability to play (according to D. Byrnes and B. Hendric, 1994 method) of wheelchair basketball players in different game positions were the following:

playmakers +13 (the best +52$)$;

forwards +18 (the best +45$)$;

centers +42 (the best +63 ).

These data were similar to the results of other studies (Skučas, Stonkus, 2002) about game analyses of wheelchair basketball players in different playing positions.

Influenced by the factors mentioned above the results of integral preparation of the wheelchair basketball center players were significantly better than those of the playmakers and forwards.

\section{CONCLUSIONS}

1. Center players were the most universal, active, and they carried out most accurate main technical actions.

2. Centers' integral preparation and playing skills were rated the highest in comparison with these values of forwards and playmakers.

3. The best players of each playing position showed similar playing skills and they were better than the average mean.
The qualitative playing results of centers were the best: shooting accuracy - 36\% (the 


\title{
REFERENCES
}

Brasile, F. (1986). Wheelchair basketball skills proficiencies vs. NWBA classification. Adapted Physical Activity Quarterly, 3, 6-13.

Brunelli, S., Traballesi, M., Averna, T. et al. (2006). Field Tests For Evaluating Elite Wheelchair Basketball Players. Rome.

Coubariaux, B. (1994). Wheelchair Athletes Classification System. IWBF.

Dewell, R. (2001). Path theory: Wheelchair tripping. Basketball News, 15 (1), 27-28.

Hendrick, B., Byrnes, D., Shaver, L. (1994). Wheelchair Basketball. USA: Paralyzed Veterans of America.

Molik, B., Kosmol, A. ( 2001). In search of objective criteria in wheelchair basketball player classification. In G. Doll-Tepper, M. Kroner, W. Sonnenschein (Eds.), Vista '99-New horizons in sport for athletes with a disability. Proceedings of the international Vista '99 conference (pp. 355-368). Koln, Germany: Meyer \& Meyer.

Molik, B., Kosmol, A. (2003). Physical ability and playing skills criteria for classifying basketball wheelchair players. Wychowanie fizyczne I sport, 3 (46), 256-261.

Skučas, K., Stonkus, S. (2002). Ivairių amplua vežimèliu krepšinio žaidèju žaidimo rodikliai. Sporto mokslas, $1(27), 69-72$.

Stonkus, S. (2001). Comparative analysis of indices of shots made by best basketball players at Atlanta and Sydney Olympic Games. Kinesiology, 2, 168-178.

Valandewijck, Y. C., Daly, D. J., Theisen, D. M. (1999). Field Test Evaluation of Aerobic, Anaerobic and Wheelchair Basketball Skill Performances. International Journal of Sports Medicine, 20, 1-7.

Valandewijck, Y. C, Evaggelinou, C., Daly, D. et al. (2003). Proportionality in wheelchair basketball classification. Adapted Physical Activity Quarterly, 20 (4), 369-380.

\section{SKIRTINGO AMPLUA VEŽIMĖLIŲ KREPŠINIO ŽAIDE்JŲ ŽAIDIMO IGŪDŽIŲ RODIKLIAI}

\author{
Kęstutis Skučas $^{1}$, Stanislovas Stonkus ${ }^{1}$, Bartosz Molik $^{2}$, Vytautas Skučas ${ }^{1}$ \\ Lietuvos kūno kultūros akademija ${ }^{1}$, Kaunas, Lietuva, Varšuvos kūno kultūros akademija ${ }^{2}$, Varšsva, Lenkija
}

\section{SANTRAUKA}

Žaidžiant vežimèlių krepšini, neigaliuju judejjimo kokybei ir judesių, veiksmų ivairovei, sensomotoriniams, intelektiniams, socialiesiems interakciniams mokejimams, koordinaciniams ir fiziniams gebejimams nustatyti ir ivertinti be natūraliujų testų (Brasile, 1986; Walandewijck, Dady, Theisen, 1999) rodiklių, objektyvūs ir informatyvūs yra kiekybiniai bei kokybiniai žaidimo rodikliai — technikos veiksmai, kuriuos atlieka žaidejjai per vienerias rungtynes ir vieną žaistą minutę (Hedrick et al., 1994 ir kt.).

Norint geriau suprasti vežimèlių krepšini, jo požymius, būtini objektyvūs kiekybiniai ir kokybiniai varžybu rodikliai, atskleidžiantys įvairias komandos žaidèjo (ižaidèjo, krašto, vidurio puolèjo) funkcijas, jų veiklos pobūdị. Tyrimų, kurių metu būtų nustatomi ir ịvertinami ịvairias funkcijas komandoje atliekantys vežimèlių krepšinio žaidèjai, aptikti nepavyko.

Tyrimo tikslas — nustatyti ir įvertinti ỉvairiu amplua vežimèlių krepšinio žaidèjų (ižaidèju, krašto, vidurio puolèju) žaidimo rodiklius oficialiose varžybose. Šiuo tikslu skaitmenine vaizdo kamera „Panasonic NV-GS27“ nufilmuotos vežimèlių krepšinio varžybos. Ištirtas 32 žaidèjų žaidimas, nufilmuota 20 rungtyniu. Žaidejjų amžius $-31,24 \mathrm{~m}$. Visi tirti žaidejai turèjo penkerių ir daugiau metų žaidimo stažą nacionaliniu ir tarptautiniu lygiu. Pagal užimamą žaidimo poziciją vežimèlių krepšinio žaidejjai buvo suskirstyti i tris grupes: ižaidèjus (9), krašto puolèjus (11), vidurio puolèjus (12). Taip pat buvo nustatomi geriausi kiekvienos pozicijos žaidėjai. Tyrimas atliktas $2006 \mathrm{~m}$. Lietuvos vežimèlių krepšinio čempionato (6 rungtynių) ir tarptautinių turnyrų (14 rungtyniu) Lietuvoje ir Lenkijoje metu. Remiantis D. Byrnes ir B. Hendrick (1994) metodika, specialiuose protokoluose buvo registruojami šie žaidimo veiksmai: žaidimo trukmė, kamuolio perdavimas, varymas, metimas i krepši ir jo veiksmingumas, kamuolio atkovojimas po krepšiu ir kiti svarbūs žaidèjų aktyvumą apibūdinantys technikos veiksmai. Integralusis parengtumas, gebejjimas žaisti, žaidimo kokybė ịvertinta pagal D. Byrnes ir B. Hendrick (1994) metodika, už atliktus veiksmus skiriant teigiamus ir neigiamus taškus.

Tyrimo rezultatai parodè, kad aktyviausi vežimèliu krepšinio žaidèjai yra vidurio puolèjai, vidutiniškai atliekantys po 2,5 veiksmo per žaistą minutę (krašto puolèjų šis rodiklis - 2,1, ižaidejjų - 1,2), kamuolị i krepši meta po 16 kartu per rungtynes (krašto puolèjai — po 7,7, ižaidèjai - po 5). Tiksliausiai pagrindinius techninius veiksmus atliko taip pat vidurio puolejjai: jų metimų i krepšs tikslumas - 36\% (krašto puolejjų ir ižaidejjų - 30\%).

Pagal atliekamų veiksmų ivairovę universaliausi taip pat buvo vidurio puolejjai: jų atliekamų pagrindinių technikos veiksmų sklaida mažiausia — kamuolio perdavimo ir kamuolio varymo veiksmai sudaro $25 \%$, metimai $i$ krepši $-20 \%$ visų atliekamų technikos veiksmu.

Integraliojo parengtumo, gebèjimo žaisti rodikliai (vertinant pagal D. Byrnes ir B. Hendrick metodiką) taip pat geriausi vidurio puolèju — + +44 taškai (krašto puolèju — +13, ižaidejjų -+11$)$. amplua.

Raktažodžiai: vežimėlių krepšinis, kiekybiniai ir kokybiniai žaidimo rodikliai, integralusis parengtumas, žaidèjų

Gauta 2009 m. gegužès 6 d.

Received on May 6, 2009
Kęstutis Skučas

Lithuanian Academy of Physical Education

(Lietuvos kūno kultūros akademija)

Sporto str. 6, LT-44221 Kaunas

Lithuania (Lietuva)

Tel +370 37302660

E-mailk.skucas@lkka.lt 